\title{
Von Willebrand Factor
}

National Cancer Institute

\section{Source}

National Cancer Institute. von Willebrand Factor. NCI Thesaurus. Code C16572.

von Willebrand factor (2813 aa, $309 \mathrm{kDa}$ ) is encoded by the human VWF gene. This protein is involved in platelet adhesion and blood coagulation. 